Provided for non-commercial research and education use. Not for reproduction, distribution or commercial use.

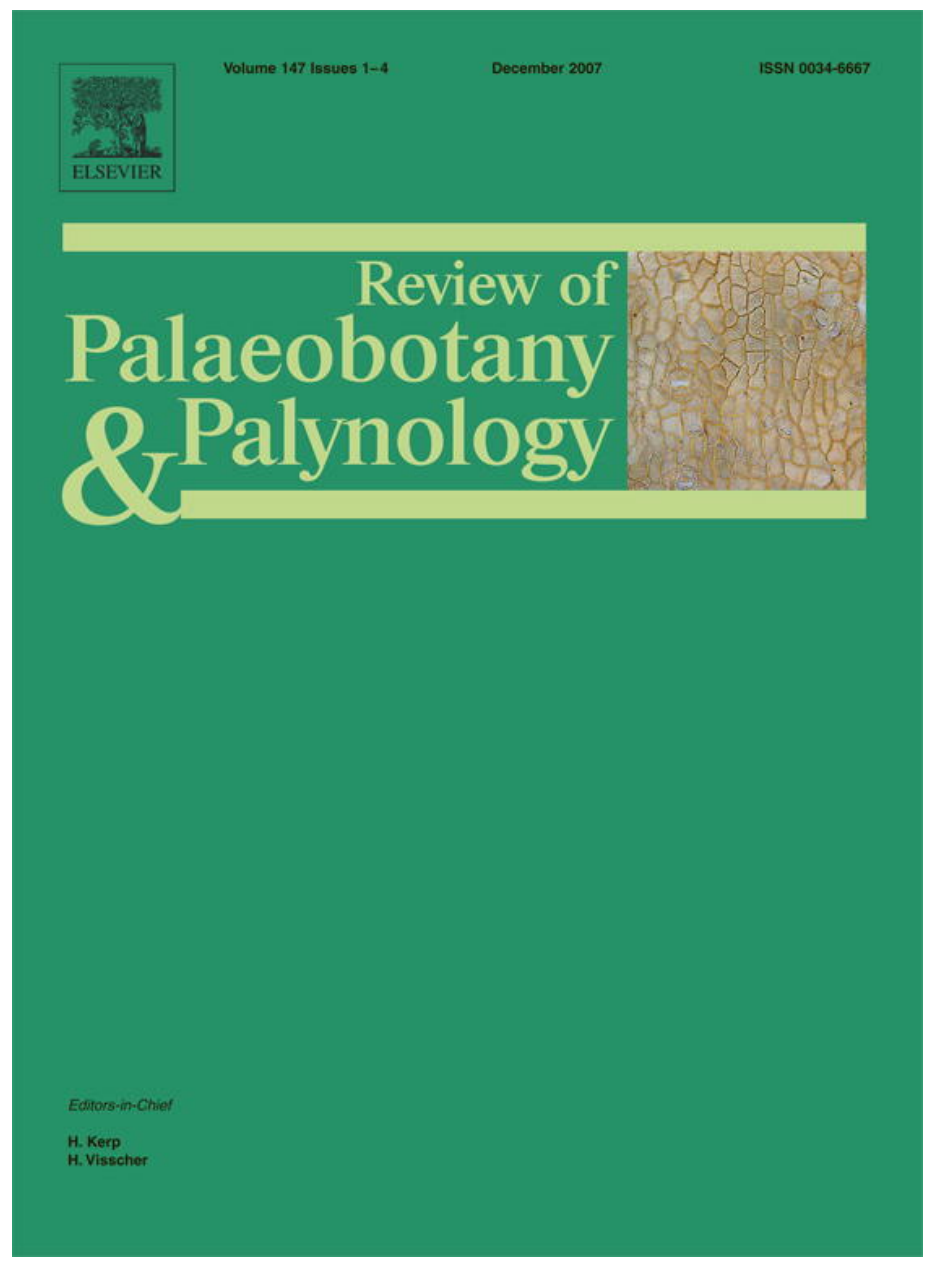

This article was published in an Elsevier journal. The attached copy

is furnished to the author for non-commercial research and education use, including for instruction at the author's institution, sharing with colleagues and providing to institution administration.

Other uses, including reproduction and distribution, or selling or licensing copies, or posting to personal, institutional or third party websites are prohibited.

In most cases authors are permitted to post their version of the article (e.g. in Word or Tex form) to their personal website or institutional repository. Authors requiring further information regarding Elsevier's archiving and manuscript policies are encouraged to visit:

http://www.elsevier.com/copyright 


\title{
Monitoring fluvial pollen transport, its relationship to catchment vegetation and implications for palaeoenvironmental studies
}

\author{
A.G. Brown ${ }^{\mathrm{a}, *}$, R.G. Carpenter ${ }^{\mathrm{b}}$, D.E. Walling ${ }^{\mathrm{b}}$ \\ a School of Geography, Southampton University, Highfields, Southampton, SO17 1BJ, UK \\ ${ }^{\mathrm{b}}$ School of Geography, Archaeology and Earth Resources, University of Exeter, Amory Building, Rennes Drive, Exeter, EX4 4RJ, UK
}

Received 2 February 2007; received in revised form 25 May 2007; accepted 7 June 2007

Available online 31 July 2007

\begin{abstract}
Despite being the most important source of pollen and spore input into most lakes and near-shore marine sediments, we know very little about fluvial (waterborne) pollen and spore transport. This paper presents the results of a dedicated monitoring programme conducted over 2 years and at a catchment scale in South West England. The land use of the nine sub-catchments monitored was determined using Landsat Thematic Data. At two stations, pollen and spore sampling through storm hydrographs was undertaken whilst at the other 7 sub-catchments only peak flow samples were collected. Samples were also collected from re-suspended bed material, riverbanks and at low flows. Airborne pollen flux was monitored using modified Tauber traps. The results support previous research illustrating how the vast majority of fluvial pollen and spores are transported during floods (in this case 91\%) and that the main control on waterborne pollen and spore assemblages is the catchment vegetation. However, strong seasonal effects are shown as well as the importance of distinctive sources, such as the riparian input, bed re-suspension and overland flow into drains and tributaries. Fine sediment in river pools appears to act as a selective store of damaged cereal-type pollen grains in arable catchments and this can reduce the inherent underestimate of arable land from pollen diagrams with a high fluvial input and increase the visibility of early agriculture. In order to simulate the likely result of a flood-dominated influx to a small lake scenario, modelling was undertaken whereby different sub-catchments were substituted in order to represent changes in catchment vegetation under a constant hydrological regime. The results show the dampened response of land use groups to catchment land use change, and the frequent occurrence of anomalous single-level peaks due to seasonal flushes from specific near-stream vegetation types. Both these features are commonly seen in lake pollen diagrams. Fluvial pollen and spore loading is dependant upon discharge and so concentrations in laminated or varved sediments could be regarded as a proxy for flood magnitude. The implications for this study on the interpretation of lake and near-shore marine pollen and spore diagrams are discussed and it is argued that a more quantitative approach to waterborne pollen could improve the estimation of land use from lakes in the temperate zone.
\end{abstract}

(C) 2007 Elsevier B.V. All rights reserved.

Keywords: waterborne pollen; palaeolimnology; palynology; pollen monitoring; vegetation history; fluvial palynomorph transport

\footnotetext{
* Corresponding author.

E-mail address: Tony.Brown@soton.ac.uk (A.G. Brown).
}

\section{Introduction}

It is widely accepted that the majority of pollen and spores entering most medium-sized and larger lakes and near-shore marine sediments are fluvially transported from river catchments (Federova, 1952; Peck, 1973; 


\section{Catchment outlets}

1. Blackball Stream at Lyshwell Farm

2. River Barle at Brushford

3. River Exe at Pixton

4. River Exe at Stoodleigh Bridge

5. River Lowman, Tiverton

6. River Dart at Bickleigh

7. River Exe at Thorverton

8. Jackmoor Brook, Yendacott Manor

9. Jackmoor Brook, Pynes Cottage

- Sampling station

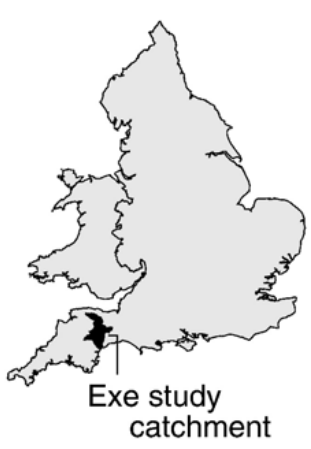

catchment

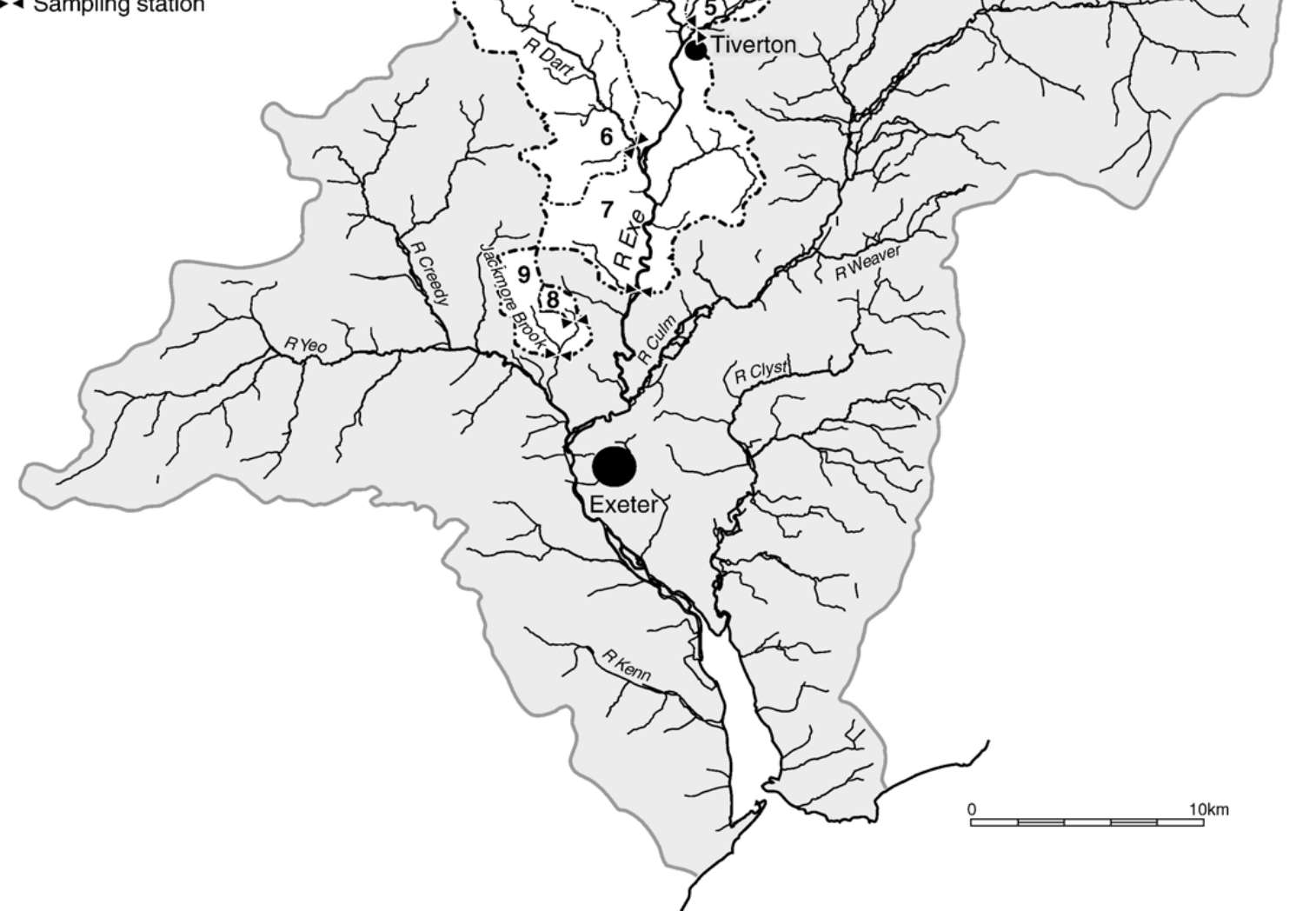

Fig. 1.

McAndrews and Power, 1973; Crowder and Cuddy, 1973; Pennington, 1979; Bonny, 1980; Brown, 1985; David and Roberts, 1990; Traverse, 1992, 1994) and that the ratio of fluvial to airborne (both wet and dry) input depends on the relationship between the size of the catchment, the lake surface area, the topography and the catchment vegetation. In classic studies, Peck (1973, 1974) found $97 \%$ of the pollen and spore input to
Oakdale reservoir was fluvial and Bonny (1978) found $87 \%$ of the input to Blelham Tarn was of fluvial origin. Fluvial pollen and spore input also forms a significant input into valley mires and alluvial wetlands. Yet we know far less about the fluvial transport of pollen and spores than we do about airborne transport and this raises the possibility that some of the features revealed in these pollen and spore diagrams may be artefacts of 
Table 1

Topographic statistics for the study catchments taken from the Flood Estimation Handbook CD-ROM

\begin{tabular}{|c|c|c|c|c|c|c|c|c|}
\hline Catchment & & $\begin{array}{l}\text { Area } \\
\left(\mathrm{km}^{2}\right)\end{array}$ & $\begin{array}{l}\text { Max drainage } \\
\text { path }(\mathrm{km})\end{array}$ & $\begin{array}{l}\text { Mean slope } \\
(\mathrm{m} / \mathrm{km})\end{array}$ & $\begin{array}{l}\text { Mean aspect } \\
(\mathrm{deg})\end{array}$ & $\begin{array}{l}\text { Catchment outlet } \\
\text { altitude (m O.D.) }\end{array}$ & $\begin{array}{l}\text { Mean } \\
\text { altitude (m O.D.) }\end{array}$ & $\begin{array}{l}\text { Max altitude } \\
\text { (m O.D.) }\end{array}$ \\
\hline 1 & Lyshwell Farm & 1.8 & 2.88 & 66.9 & 93 & 287 & 345 & 378 \\
\hline 2 & Brushford & 128.8 & 40.99 & 136.4 & 152 & 128 & 245 & 488 \\
\hline 3 & Pixton & 149.8 & 36.79 & 153.8 & 185 & 128 & 307 & 519 \\
\hline 4 & Stoodleigh & 420.7 & 55.44 & 142.5 & 168 & 74 & 284 & 519 \\
\hline 5 & Tiverton & 54.5 & 15.87 & 95.1 & 192 & 62 & 168 & 286 \\
\hline 6 & Bickleigh & 45.4 & 14.33 & 146.2 & 132 & 52 & 176 & 271 \\
\hline 7 & Thorverton & 608.9 & 76.92 & 137.8 & 164 & 26 & 244 & 519 \\
\hline 8 & Yendacott & 1.5 & 2.38 & 48.9 & 161 & 35 & 59 & 85 \\
\hline 9 & Pyne Cottage & 9.3 & 5.48 & 58 & 158 & 25 & 66 & 235 \\
\hline
\end{tabular}

the dynamics of fluvial transport rather than simply reflecting changes in the surrounding vegetation. This paper presents the result of basin-scale monitoring of fluvial pollen and spore transport and uses this data to make inferences concerning the interpretation of lake and near-shore marine pollen and spore diagrams.

However, studies of fluvial pollen and spore transport although rare have revealed that flood concentrations can be from 100,000 grains $1^{-1}$ (Peck, 1974) to as high as $130,000-230,000$ grains $1^{-1}$ (Brown, 1985). Pollen and spores transport has also been investigated in flumes (Brush and Brush, 1972) and Holmes (1990, 1994) reported no differential sorting at velocities over $0.30 \mathrm{~m}^{-1} \mathrm{~s}^{-1}$ and Meade et al. (1990) also report that flood pollen is well mixed. Assuming this is the case, then we can define the fluvial pollen and spore load as being the combination of several distinct components including the airborne component (directly into the channels from local to regional sources), the riparian component (including leaf drip), the overland flow component, the bank erosion component and river storage in bed-sediments that can be resuspended in floods.

Using the analogy with forest gaps and lakes (Jacobson and Bradshaw, 1981) for rivers under $30 \mathrm{~m}$ wide, the significant terms can be reduced to the riparian, overland flow (especially into tributaries), bank erosion and river storage components. However, there is little data on the relative input of these components and the sampling strategy employed in this study was designed to allow some quantification of these different input sources.

\section{Study site information}

The site chosen for this study was the Exe Basin in SW England (Fig. 1). The River Exe drains an area of $1530 \mathrm{~km}^{2}$; its source rises at Exe Head on Dure Down, Exmoor (SS 752415) and flows $87.2 \mathrm{~km}$ west and south until it reaches the Exe Estuary at Exmouth. The Exe catchment was chosen for this study because it exhibits considerable and systematic diversity with regards to vegetation cover, hydrological regimes and climatic conditions (Walling and Moorehead, 1987). Thirteen sub-catchments were monitored (data from 9 is used here) in order to sample this variety. Within the Exe catchment there is an established hydrometric monitoring network operated by the University of Exeter and the Environment Agency, providing suitable monitoring data along with the availability of meteorological data supplied by the British Atmospheric Data Centre. Finally, the Exe catchment has been extensively studied and there is consequently a large amount of literature relating to catchment sediment dynamics (for example, Walling and Webb, 1981; Walling and Woodward, 1993; Walling et al., 1993; Walling and He, 1994; Nicholas and Walling, 1995; Collins et al., 1997a,b; Blake et al., 2002; Collins and Walling, 2002). The geology of the catchment is dominated by Devonian sandstones, slates and conglomerates in the north, and Carboniferous sandstones, conglomerates and mudstones in the middle and south and one area of Cretaceous Upper greensand in the east. The catchment lay outside the maximum Pleistocene glacial limits and has a well-developed strath terrace staircase and basin and gorge type floodplain. The relative relief of the catchment is $519 \mathrm{~m}$ and slopes are steepest in the headwaters. The average slope angle is $17^{\circ}$ (Webb, 1980) but with considerable variation in the subcatchments (Table 1). The catchment has a mean annual precipitation of $1097 \mathrm{~mm}$ but this also varies in the subcatchments from 900 to $3262 \mathrm{~mm} \mathrm{yr}^{-1}$ (Table 1). The mean daily flow at Thorverton is $9 \mathrm{~m}^{3} \mathrm{~s}^{-1}$ with 0.01 probability of exceedence flow being $90 \mathrm{~m}^{3} \mathrm{~s}^{-1}$ and the 0.99 probability being $1.4 \mathrm{~m}^{3} \mathrm{~s}^{-1}$. Vegetation cover and land use was extracted from the Land Cover Map of Great Britain (1990) produced from Landsat Thematic Data (Fuller et al., 1994). Little land use change has 
Table 2

Simplified land cover and associated pollen taxa

\begin{tabular}{|c|c|}
\hline $\begin{array}{l}\text { Simplified land cover } \\
\text { class }\end{array}$ & Associated pollen taxa \\
\hline Disturbed ground & $\begin{array}{l}\text { Papaver rhoeas-type, Chenopodiaceae, Urtica-type, Hypericum perforatum-type, Brassicaceae, Apiaceae, Lamiaceae } \\
\text { undiff., Mentha-type, Scrophularia-type, Rhinanthus, Valeriana officinalis, Arctium-type, Artemisia-type. }\end{array}$ \\
\hline Pasture & $\begin{array}{l}\text { Ranunculus, Caryophyllaceae, Polygonum, Rumex acetosella, Rumex acetosa, Umbilicus rupestris-type, Potentilla-type, } \\
\text { Astragalus danicus-type, Lotus, Medicago sativa, Trifolium-type, Gentianella campestris-type, Plantago lanceolata, } \\
\text { Digitalis purpurea-type, Scabiosa columbaria, Cirsium-type, Centaurea nigra, Lactuceae, Solidago virgaurea-type, Aster- } \\
\text { type, Poaceae undiff. }\end{array}$ \\
\hline Marsh & $\begin{array}{l}\text { Sphagnum, Caltha palustris-type, Persicaria bistorta-type, Montia fontana, Filipendula, Gentiana-type, Valeriana dioica, } \\
\text { Succisa pretensis, Cyperaceae undiff. }\end{array}$ \\
\hline Heath/Moorland & Lycopodium, Juniperus communis, Betula, Vaccinium-type, Calluna vulgaris, Ulex-type. \\
\hline Bracken & Pteridium aquilinum. \\
\hline Deciduous woodland & $\begin{array}{l}\text { Pteropsida monolete undiff., Polypodium, Dryopteris-type, Ulmus, Juglans regia, Fagus sylvatica, Quercus, Alnus } \\
\text { glutinosa, Corylus avellana-type, Tilia cordata, Populus, Salix, Rhododendron ponticum, Ribes, Rubus, Rosa, Sorbus- } \\
\text { type, Ilex aquifolium, Acer campestre, Hedera helix, Fraxinus excelsior, Sambucus. }\end{array}$ \\
\hline Coniferous woodland & Abies, Picea, Pinus sylvestris. \\
\hline Arable & Avena-type, Hordeum-type, Secale cereale, Zea mays. \\
\hline
\end{tabular}

occurred during the intervening years due to physical limitations and conservation controls on agriculture in the area and this allowed the land use in each of the subcatchments to be quantified from the predominantly pasture and heathland (sub-catchments 1-3), predominantly pasture and deciduous woodland (sub-catchments 4 and 6), predominantly pasture and arable (catchments 5 and 7) and predominantly arable cultivation (catchments 8 and 9).

\section{Field, laboratory and modelling methods}

Peak flow samples were taken from the outlet of each of the sub-catchments during floods over a period of 24 months. In addition background low flow samples were collected and at two stations samples were taken through storm events (hydrograph samples). Samples were taken either using a submersible pump and portable generator or by hand from the middle of the river at an approximate height of $0.6 \times$ the maximum river depth. This was done in order to ensure that the water was fully mixed and avoided the problem of surface water assemblages being biased towards more buoyant and unsaturated pollen grains (Hopkins, 1950; Traverse and Ginsburg, 1966; Traverse, 1988). This assumption was also tested by sampling a depth profile at an intermediate flow (see Results). The volume of water samples was varied depending upon the suspended sediment concentration from as much as 101 at sites with low concentrations (e.g. catchment 1, Lyshwell Farm) to only 21 (Catchment 9, Pyne Cottage).

In addition samples were taken of the bed sediment in a pool and riffle using a $1 \mathrm{~m}$ high steel cylinder pushed into the bed and the water agitated before sampling
(Lambert and Walling, 1988). This sediment resuspension technique was adopted in order to sample the pollen which could be re-suspended during a flood event. Eight samples were also taken from an actively eroding riverbank in the Bickleigh reach of the River Dart (sub-catchment 6). All the water samples were filtered (some after centrifugation at $2500 \mathrm{rpm}$ for $10 \mathrm{~min}$ ) using glass fibre Whatman filters (GF/A) with a pore size of $1.6 \mu \mathrm{m}$. The filters were then oven-dried and the suspended sediment weight recorded before they were subjected to a standard chemical processing using hydrofluoric acid digestion followed by acetolysis. Pollen concentrations were determined by the addition of Lycopodium clavatum tablets containing a known number of spores (Stockmarr, 1971). Pollen identification routinely used $\times 400$ magnification with $\times 1000$ magnification for small and difficult types with reference to standard keys (Andrew, 1984; Faegri and Iversen, 1989; Moore et al., 1991) and the Exeter University Pollen and Spore reference collection. Pollen and spore nomenclature follows Bennett et al. (1994). Pollen preservation was recorded using a three-fold classification adapted from Delcourt and Delcourt (1980); corroded, degraded and mechanically damaged. Where more then one form of degradation was present only the most developed was recorded.

At each of the sub-catchment sampling stations airborne pollen flux was also monitored using a modified Tauber trap (Tauber, 1974; Hicks and Hyvärinen, 1986) with a central aperture of $5 \mathrm{~cm}$ diameter and sloping collar of $15 \mathrm{~cm}$ diameter. The traps were located in an open area of at least $30 \mathrm{~m}$ in diameter. Two traps were located adjacent to each stream sampling location, the results averaged and the traps were emptied after each rainfall 


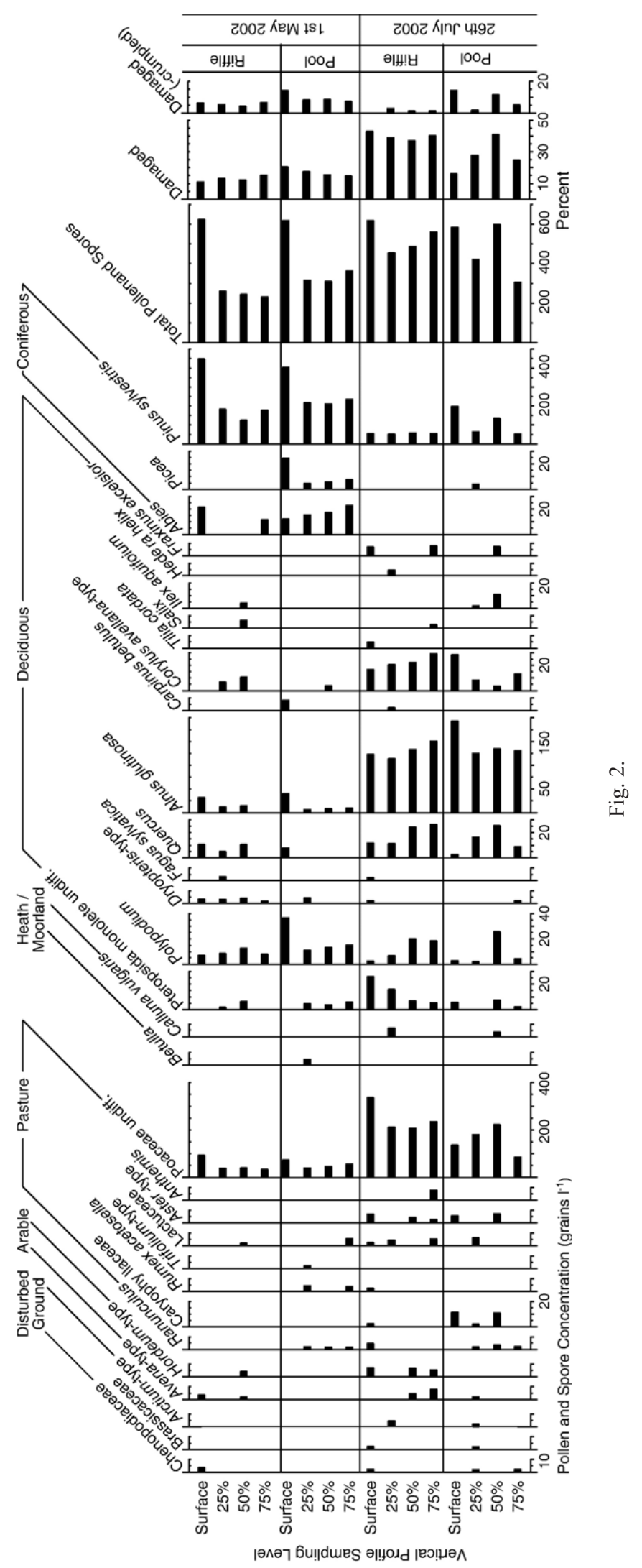


River Dart at Bickleigh (catchment 6)

a. Pollen types (concentration) 23 Jan 2001
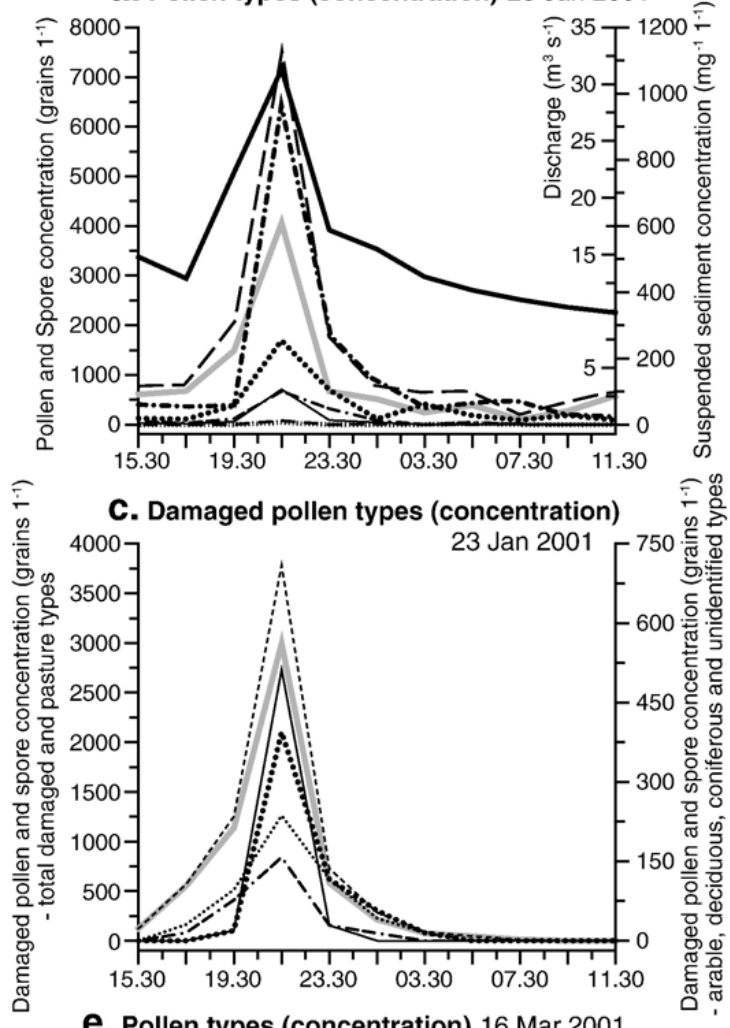

e. Pollen types (concentration) 16 Mar 2001
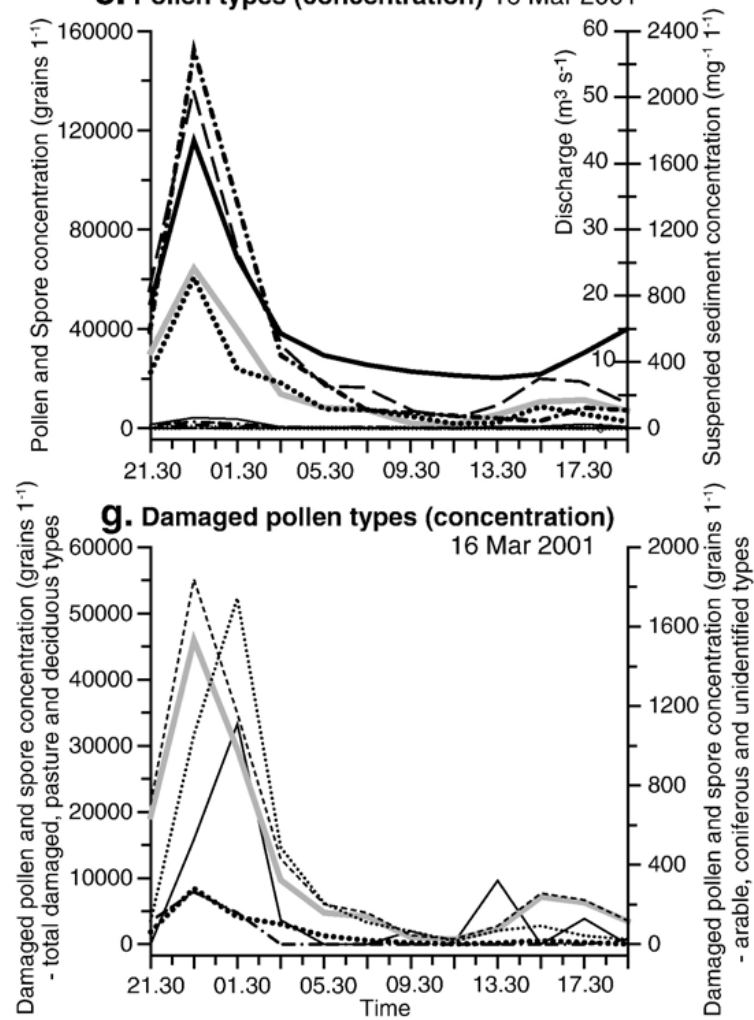

River Exe at Thorverton (catchment 7)

b. Pollen types (concentration) 23 Jan 2001

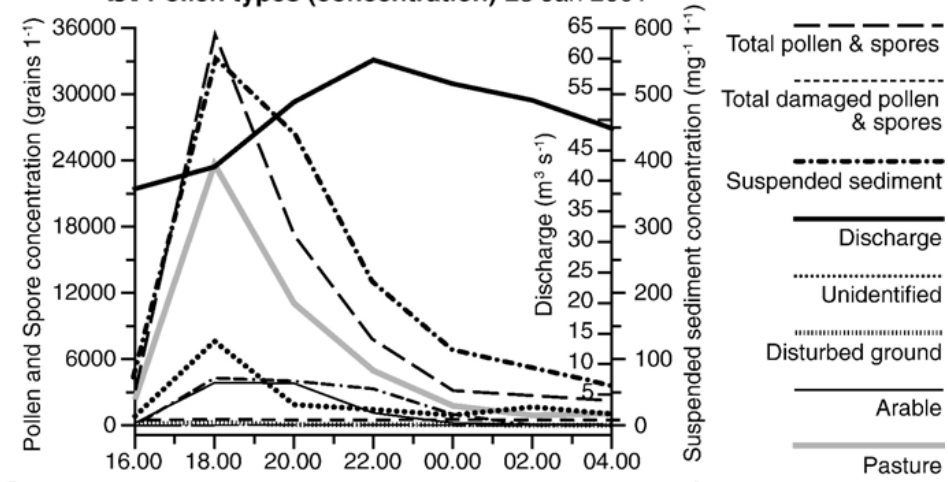

\section{을}

Heath /Moorland

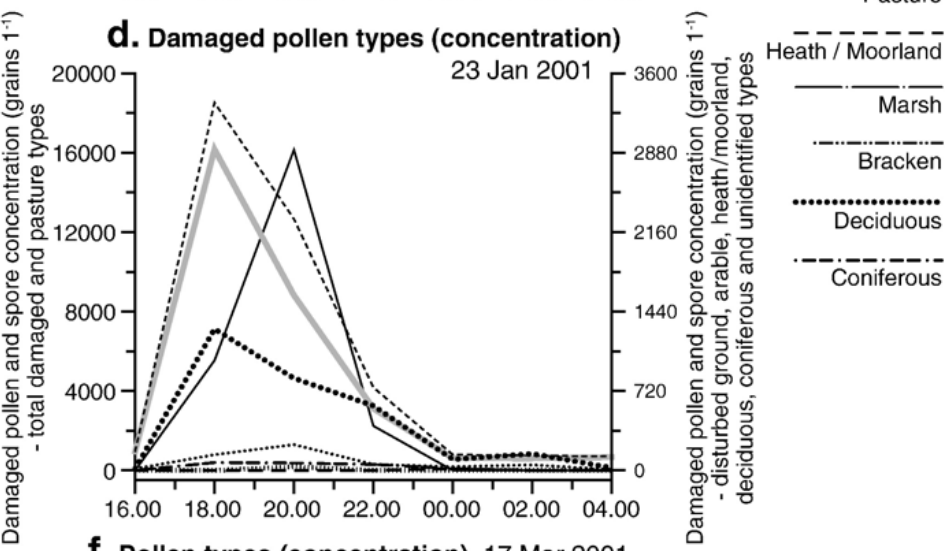

f. Pollen types (concentration) 17 Mar 2001
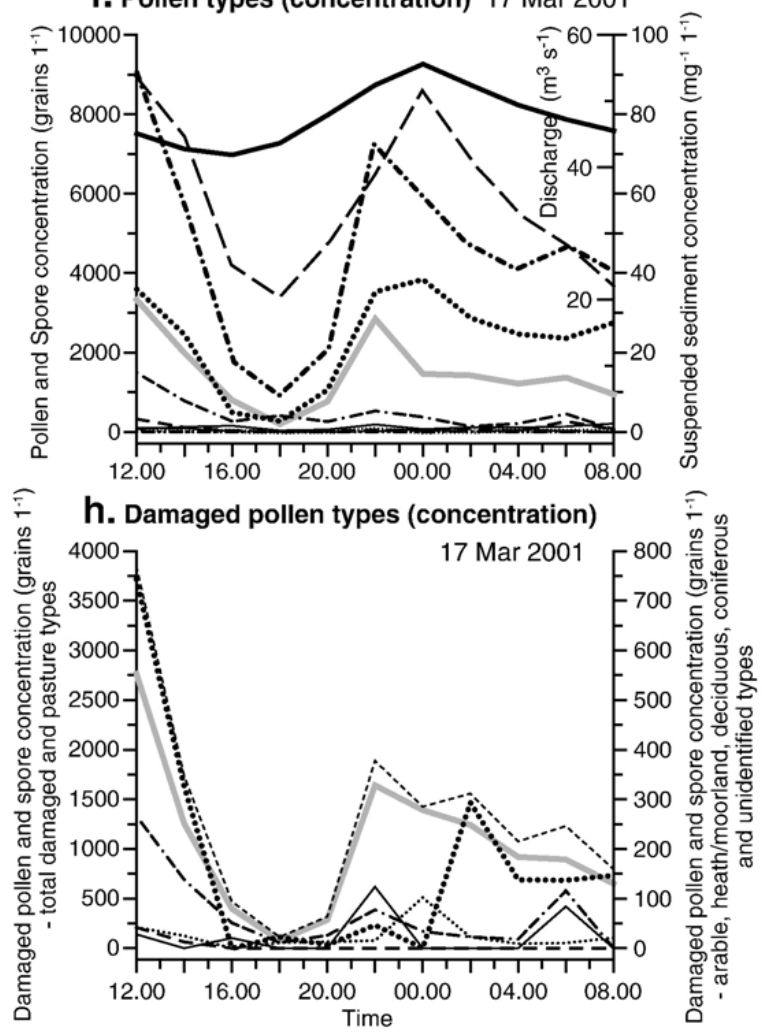

Fig. 3.

In order to be able to compare the pollen data with the land use data it was necessary to convert the pollen and spore data into 8 vegetation/land use classes (Table 2).

event or in dry periods each month. The traps were not meshed and the samples were processed in the same manner as the water and bank samples. 
River Dart at Bickleigh (catchment 6)

a. Pollen types (concentration) 22 Apr 2001
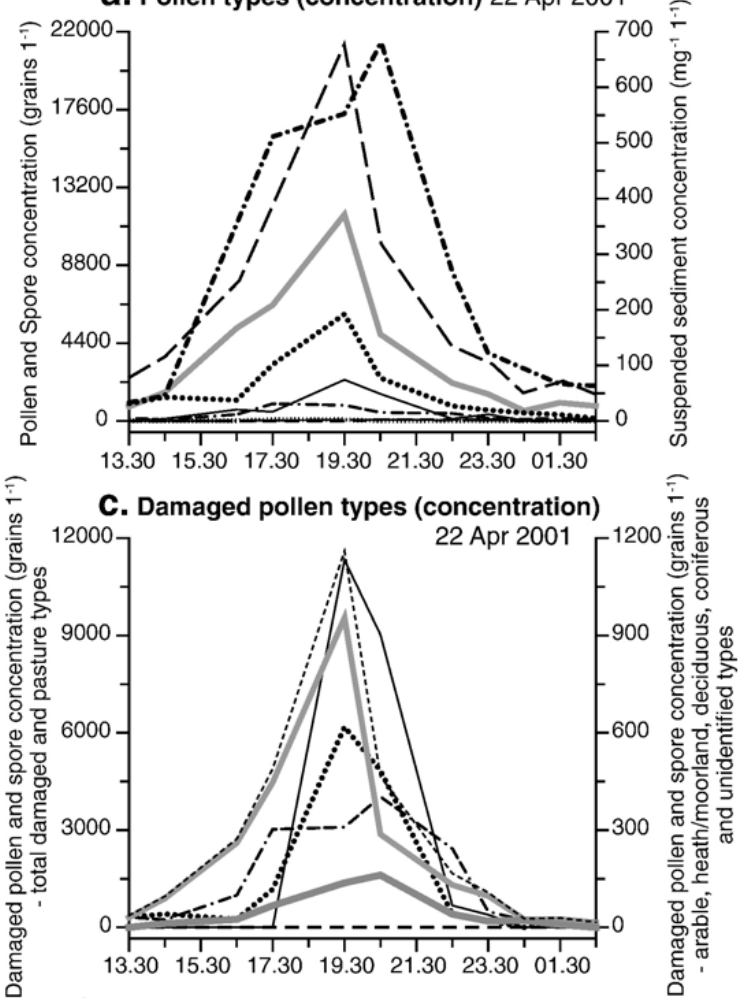

e. Pollen types (concentration) 26 Oct 2001
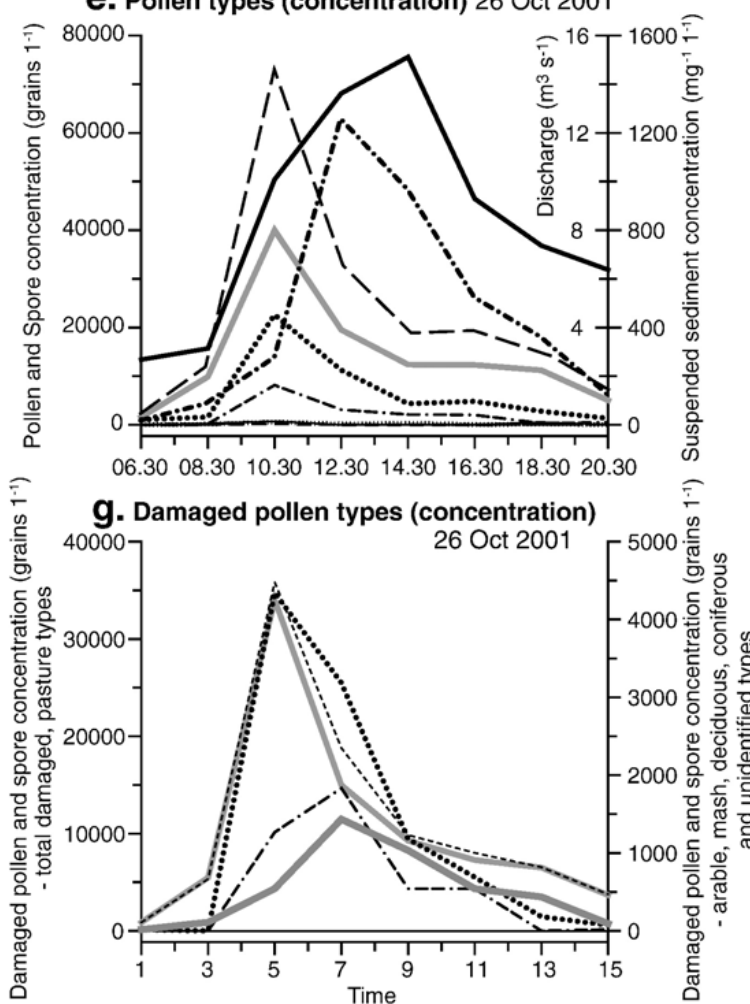

River Exe at Thorverton (catchment 7)

b. Pollen types (concentration) 22 Apr 2001

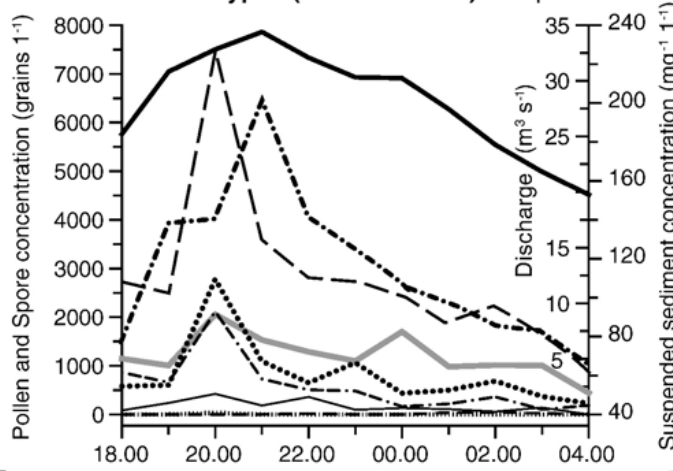

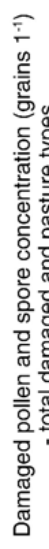

d. Damaged pollen types (concentration)

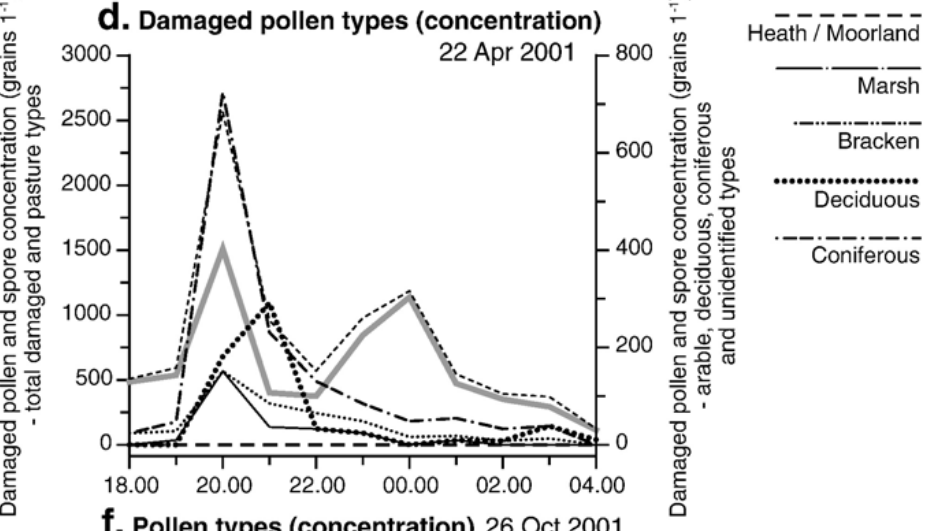

Total pollen \& spores Total damaged pollen

Suspended sediment

Disturbed ground

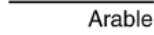

Pasture

orland

Coniferous
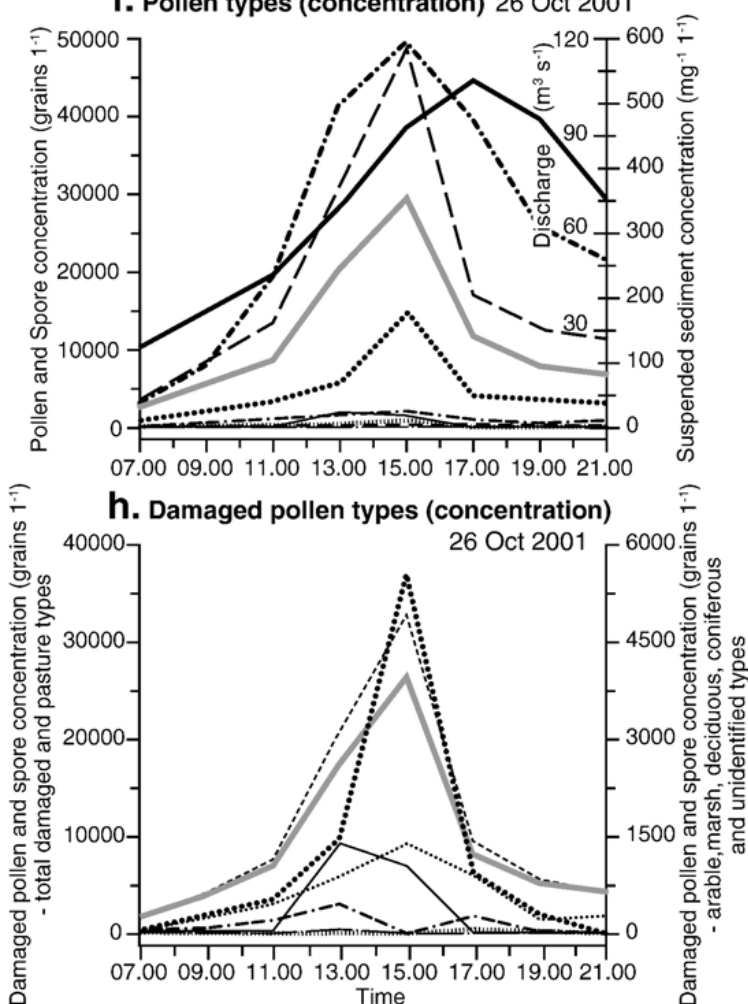

Fig. 4.
This is problematic due to problems of taxonomic precision but was done using the ecology of the dominant species in each of the pollen types sensu Bennett et al.
(1994). There are clearly some species of a different ecology within these groups but the overwhelming majority in pollen-producing terms will have been derived 

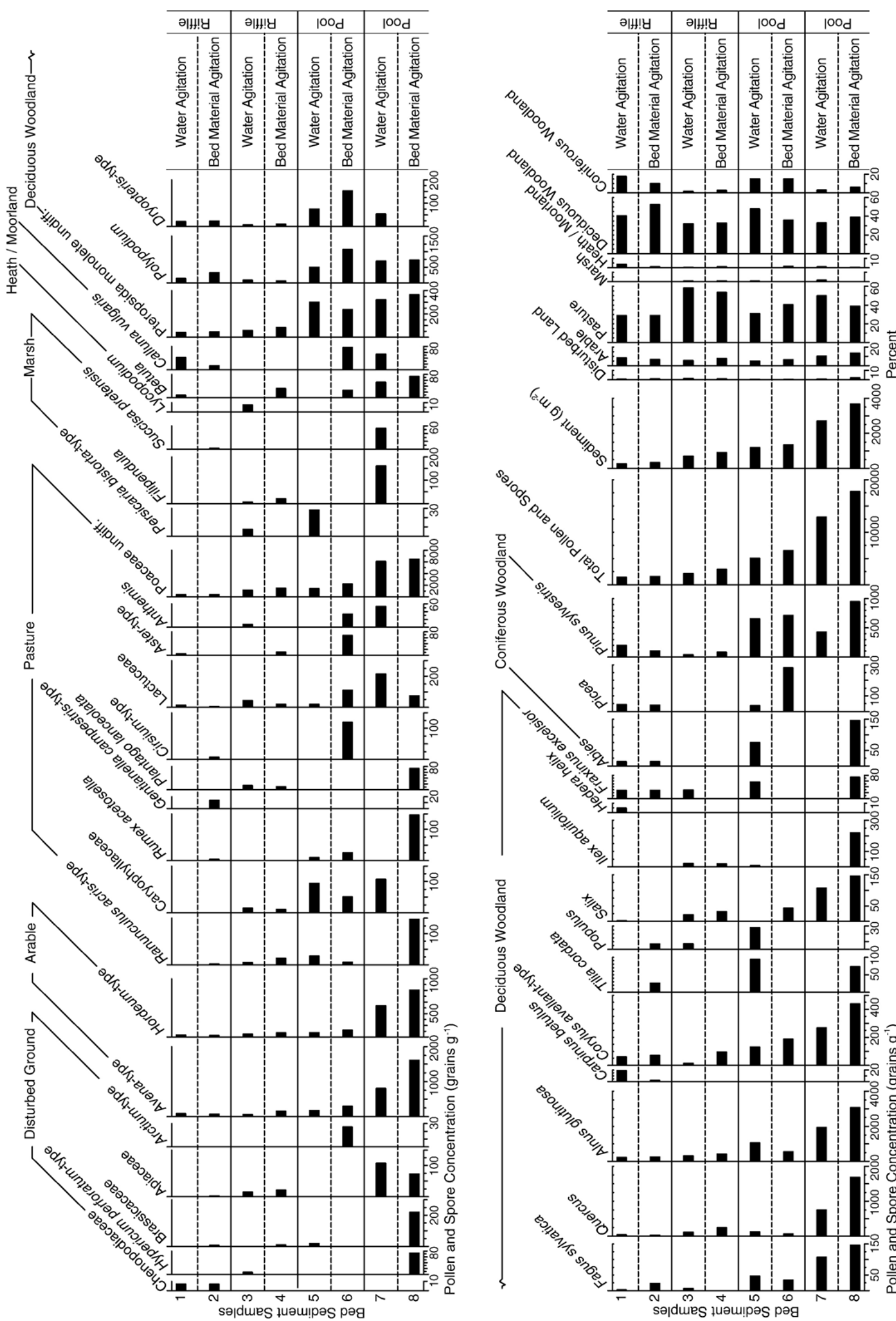

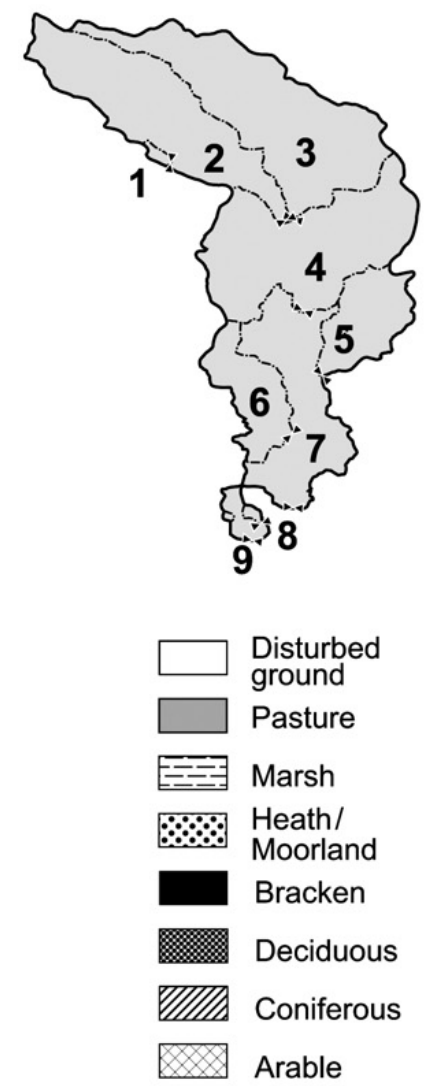

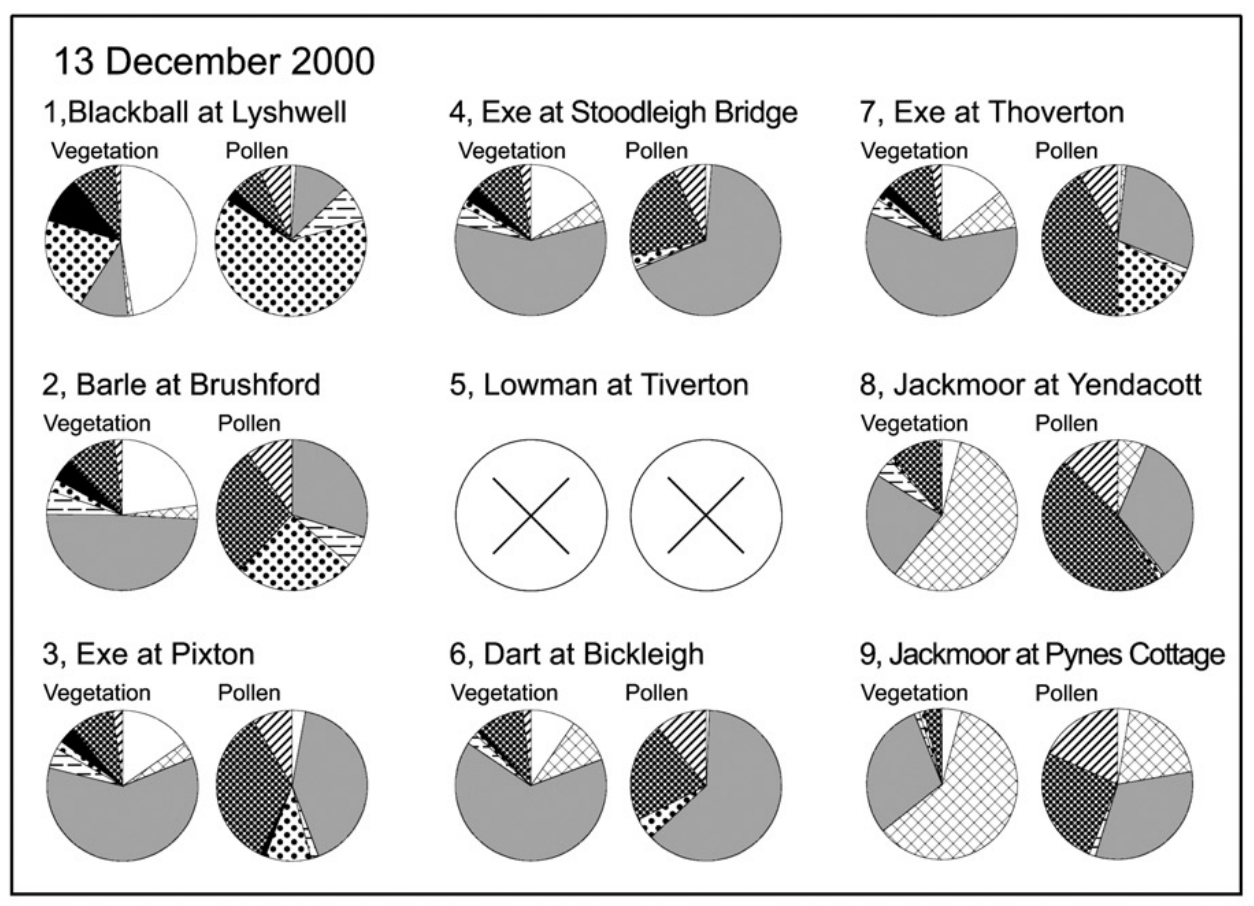

22 January 2001

1,Blackball at Lyshwell Vegetation Pollen

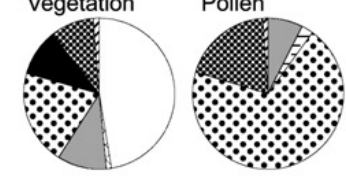

2, Barle at Brushford Vegetation

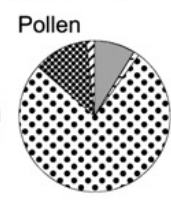

3, Exe at Pixton Vegetation
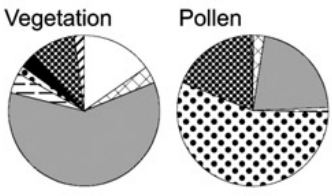

4, Exe at Stoodleigh Bridge

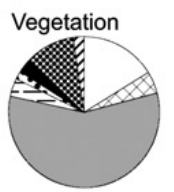
Pollen

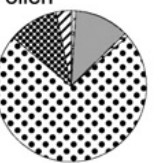

\section{5, Lowman at Tiverton} Vegetation
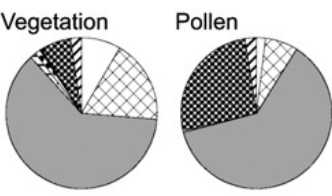

\section{6, Dart at Bickleigh} Vegetation

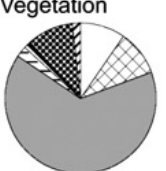

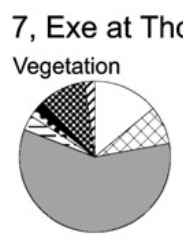

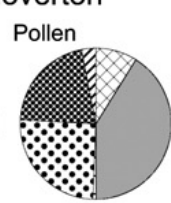

8, Jackmoor at Yendacott Vegetation Pollen
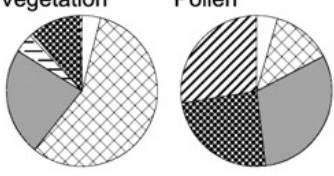

9, Jackmoor at Pynes Cottage Vegetation
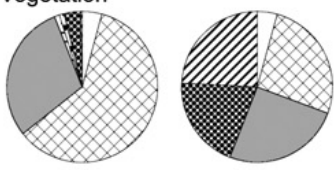

Fig. 6.

from that vegetation type (e.g. Ranunculus includes aquatic species but the vast majority of pollen will be from pasture species). The scenario modeling was undertaken by using the monitored fluvial pollen output for a subcatchment and repeating it for several annual cycles and then substituting another sub-catchment with a different land use and repeating the procedure. In effect, it is an application of the ergodic approach (space for time substitution) using the monitored data in order to estimate what the effect of a land use change might be on the fluvial input to a lake or near-shore marine sediments.

\section{Results}

\subsection{Pollen and spore hydrographs}

Sampling of the vertical water profile (Fig. 2) showed the pollen and spores to be well mixed but with a distinctly 


\section{Catchments}
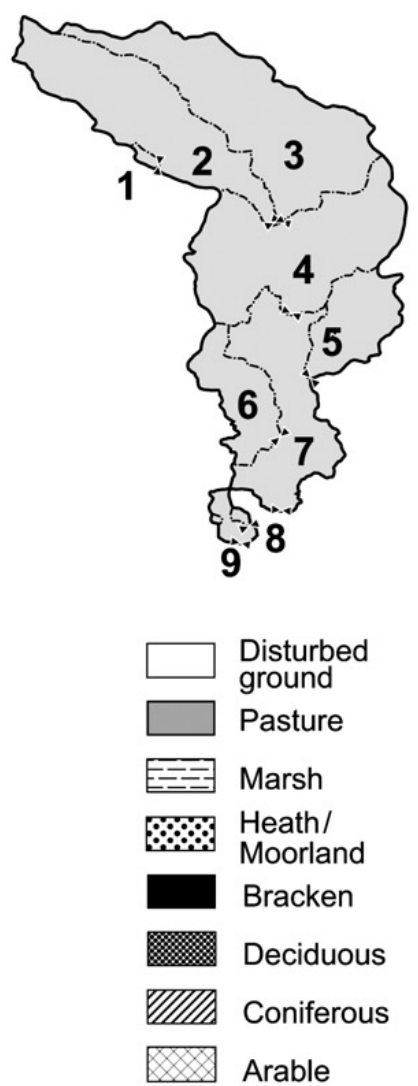

\section{March 2001}

1 ,Blackball at Lyshwell

Vegetation
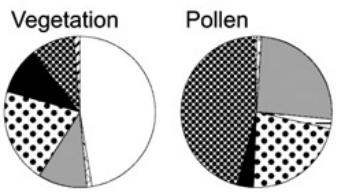

2, Barle at Brushford
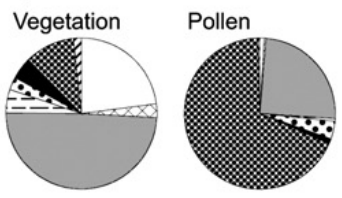

3, Exe at Pixton

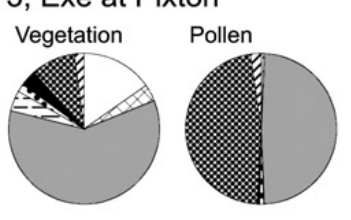

06 July 2001

1,Blackball at Lyshwell

Vegetation Pollen
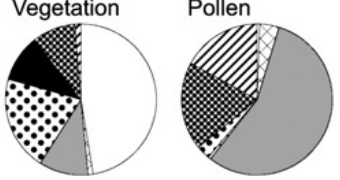

2, Barle at Brushford
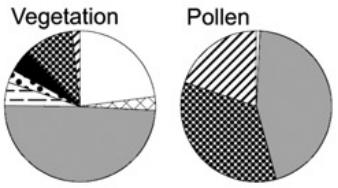

3, Exe at Pixton
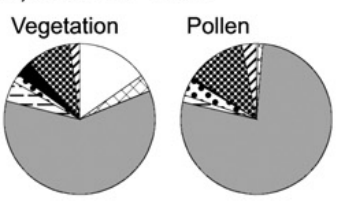

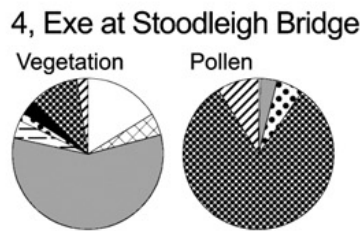

5, Lowman at Tiverton

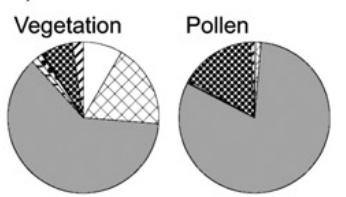

6, Dart at Bickleigh
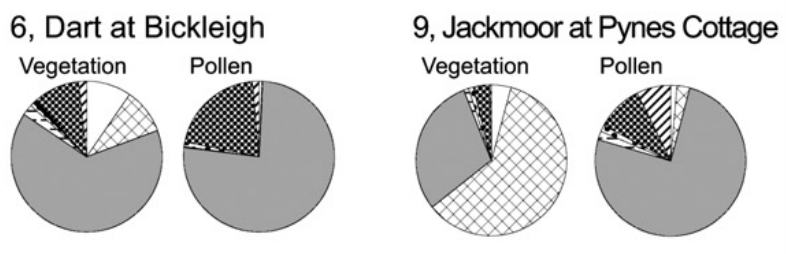

8, Jackmoor at Yendacott
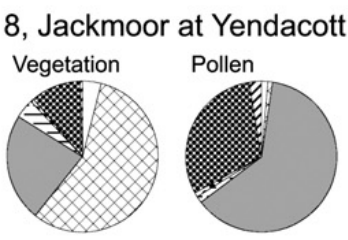

7, Exe at Thoverton

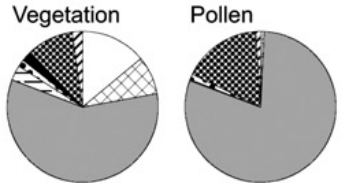

4, Exe at Stoodleigh Bridge

7, Exe at Thoverton

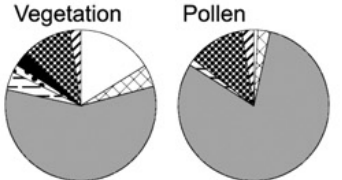

5, Lowman at Tiverton

Vegetation Pollen
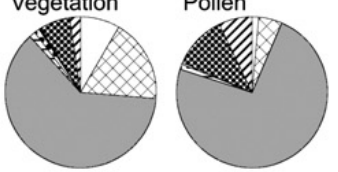

6, Dart at Bickleigh

Vegetation
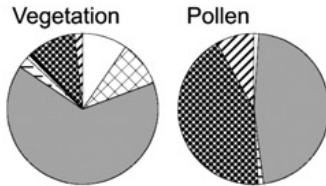
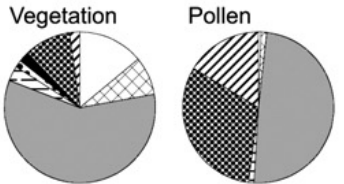

8, Jackmoor at Yendacott
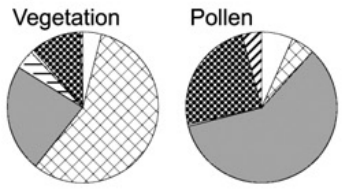

9, Jackmoor at Pynes Cottage
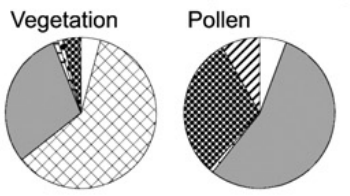

Fig. 7.

higher concentration $(50 \%-20 \%)$ at the water surface (Brown et al., in press). This has been reported by Traverse and Ginsburg (1966) and Traverse (1988) who regard it as a function of the saturation time of airborne inputs. Starling and Crowder (1981) also observed significantly higher concentrations of pollen towards the surface of the Salmon River a phenomena also reported by Smirnov et al. (1996) who observed a high degree of variation within the vertical profile (600-2300 grains $1^{-1}$ ) with the highest concentrations of Pinus and Salix occurring at the surface. Smirnov et al. (1996) suggests that this high surface concentration is due to input from riparian vegetation. However, as Brush and Brush (1972) had already shown once saturated transport is mixed and unsorted.

Sampling through floods at Bickleigh and Thorverton confirm the dramatic increase in pollen and spore concentration through the flood hydrograph with peak concentrations at Bickleigh reaching 7000 grains $1^{-1}$ even on January 23rd 2001 (Fig. 3) and coincident with the peak in discharge and suspended sediment. At Thorverton 
peak concentration are even higher for the same event reaching 35,000 grains $1^{-1}$ coincident with the peak in suspended sediment but preceding the peak discharge (Fig. 3). Damaged grains show a similar trend but with the second highest concentration being of arable types which at Thorverton is lagged behind the other types. These concentrations are too high to simply be derived from the channel bed and banks and so indicate pollen being washed in from other sources such as overland flow into tributaries and drains as well as some riparian wash-off. Unsurprisingly spring hydrographs show even higher concentrations reaching 150,000 grains $1^{-1}$ at Bickleigh but only 7000 grains $1^{-1}$ at Thorverton (Fig. 4) probably due to the location of the storm over the Dart Catchment. Arable types are again disproportionately high. In April, peak concentrations reach 22,000 grains $1^{-1}$ with damaged arable types alone reaching 11,000 grains $1^{-1}$ (Fig. 5). Autumn hydrographs (Fig. 6) show a fall in peak concentrations to 7000 grains $1^{-1}$ and 50,000 grains $1^{-1}$ and arable types, both undamaged and damaged become proportionately less important whilst deciduous types become more important.

The relatively high proportion of damaged grains, and particularly those of the arable group is echoed in the river bed samples (Fig. 7). These show that even in the Dart sub-catchment which is predominantly pasture and woodland Avena type is the second highest after

Table 3

The low flow (95\% duration) and high flow (5\% duration) pollen loads calculated for Thorverton from November 200 to October 2001 in grains $\times 10^{12}$

\begin{tabular}{lclc}
\hline Month & $\begin{array}{l}\text { Total flood } \\
\text { flow pollen and } \\
\text { spore loading } \\
\left(\times 10^{12} \text { grains }\right)\end{array}$ & $\begin{array}{l}\text { Total low flow } \\
\text { pollen and } \\
\text { spore loading } \\
\left(\times 10^{12} \text { grains }\right)\end{array}$ & $\begin{array}{l}\text { Total monthly } \\
\text { pollen and spore } \\
\text { load }\left(\times 10^{12} \text { grains }\right)\end{array}$ \\
\hline $\begin{array}{c}\text { November } \\
\text { 2000 }\end{array}$ & 13.195 & 17.168 & 30.363 \\
December & 6.021 & 5.602 & 11.624 \\
$\quad$ 2000 & & & \\
January 2001 & 135.112 & 9.824 & 144.937 \\
February & 233.882 & 19.733 & 253.616 \\
2001 & & & \\
March 2001 & 139.257 & 6.931 & 146.188 \\
April 2001 & 46.888 & 2.081 & 48.969 \\
May 2001 & 21.767 & 1.132 & 22.900 \\
June 2001 & 6.986 & 1.274 & 8.261 \\
July 2001 & 0.777 & 6.931 & 7.708 \\
August 2001 & 19.887 & 2.002 & 21.889 \\
September & 6.330 & 0.463 & 6.794 \\
$\quad 2001$ & & & 272.862 \\
October & 258.483 & 14.379 & 976.117 \\
$\quad 2001$ & & & \\
Total 2000- & 888.591 & 87.525 & \\
2001 & & & \\
\hline
\end{tabular}

Poaceae reaching over 1500 grains $\mathrm{g}^{-1}$. Nearly all of these grains were broken, crumpled or degraded providing a potential signature of this pollen component. This is an important potential store of pollen and is probably the source for much of the degraded pollen observed in the flood samples.

\section{Flood and low flow comparisons}

The monitoring of pollen and spore concentrations during both low flow and floods at Thorverton and constant measurement of discharge has allowed an estimate to be made of the total pollen and spore loading at low flows ( $<95 \%$ flow duration) and floods (5\% flow duration) leaving the majority of the basin (Table 3). As Table 3 shows that, for 9 out of the 12 months (November 2000-October 2001), the flood load exceeded the low flow load. Additionally in the months January-June the flood loading was $15-23 \times$ that of the low flow. The result is that over the year the flood flows carried $91 \%$ of the total pollen and spores that left the upper and middle Exe catchment.

\section{Sub-catchment flood samples and vegetation}

Samples taken at a flood peak on the 13 th of December 2000 show significant inter-catchment variations (Fig. 8A) which in general reflect the sub-catchment variation. The upper pasture and heath dominated sub-catchments show large relative proportions for pasture and heath. The correspondence for the middle pasture dominated catchments (4 and 6) is particularly strong and the high arable land use of the lower catchments is reflected in the pollen and spore proportions. However, there are differences and most notably exaggerations in the pollen and spore proportions (in relation to the percentage of land use in each catchment) particularly of heathland and deciduous in catchments 2 and 3, heathland in catchment 1 as well as underestimates such as the arable types in all subcatchments even though the values are extremely high in comparison to most pollen diagrams at $10 \%-20 \%$ total land pollen. Very similar results were derived from a flood on 22nd January 2001 (Fig. 8B) with even greater exaggeration of heathland and arable reaching $25 \%$ in sub-catchment 9. A particular feature of this storm is the peak in Calluna from the Blackball sub-catchment (1) which reached a concentration of 7241 grains $1^{-1}$ at Lyshwell Farm which was $66 \%$ of the total concentration. Even at the lowest monitoring station at Thorverton this Calluna flush still made up $25 \%$ of the total basin output. By March 2001, the situation had changed with a universal over-representation of deciduous types due largely to the 
Catchments 1 to 9
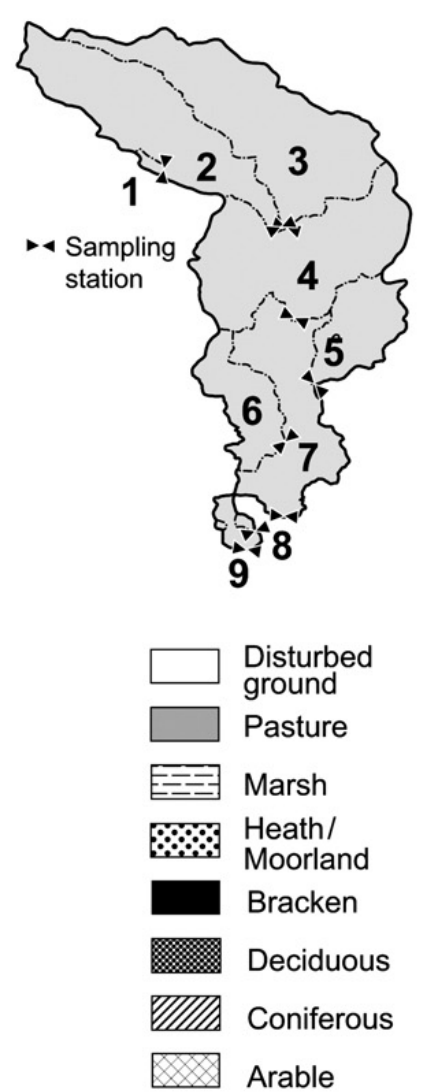

\section{October 2000}

1 ,Blackball at Lyshwell

Vegetation

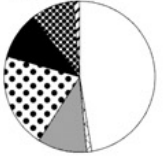

Pollen

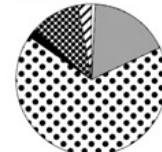

2, Barle at Brushford
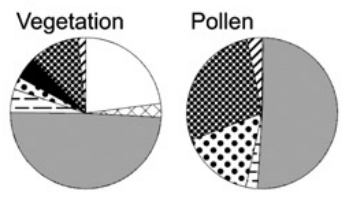

3, Exe at Pixton

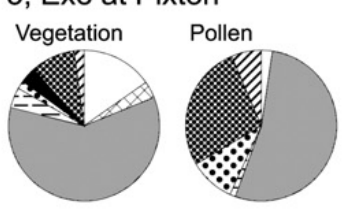

4, Exe at Stoodleigh Bridge Vegetation
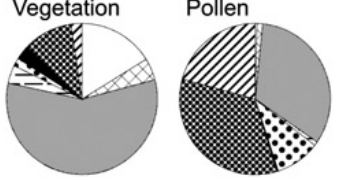

5, Lowman at Tiverton

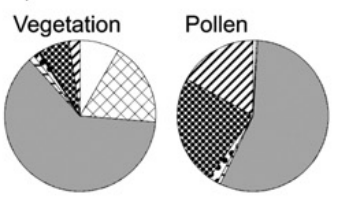

6, Dart at Bickleigh

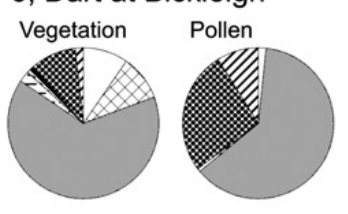

7, Exe at Thoverton

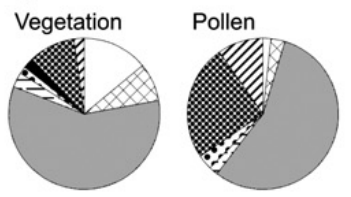

8, Jackmoor at Yendacott

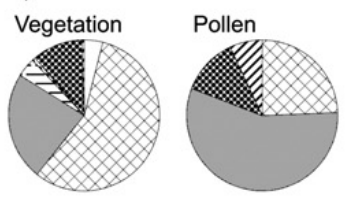

9, Jackmoor at Pynes Cottage
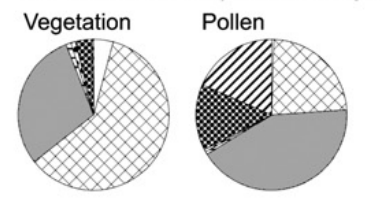

26 October 2001

1,Blackball at Lyshwell

Vegetation
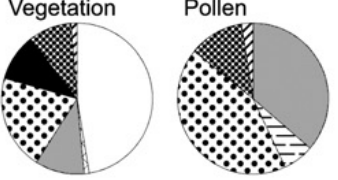

2, Barle at Brushford
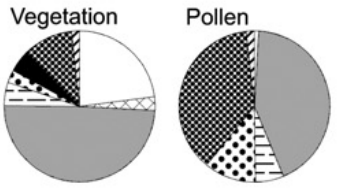

3, Exe at Pixton
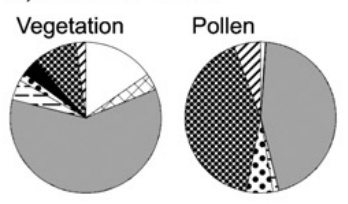

4, Exe at Stoodleigh Bridge
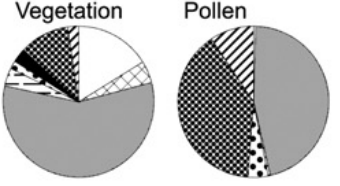

5, Lowman at Tiverton
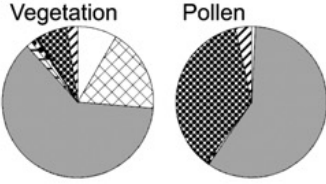

6, Dart at Bickleigh Vegetation
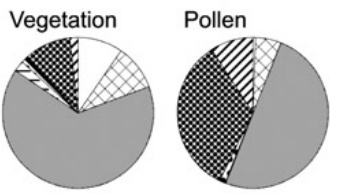

\section{7, Exe at Thoverton}
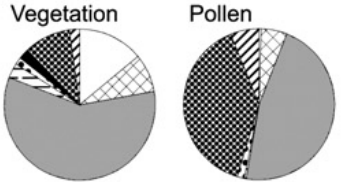

8, Jackmoor at Yendacott
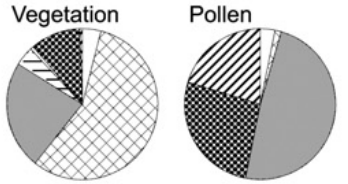

9, Jackmoor at Pynes Cottage Vegetation Pollen
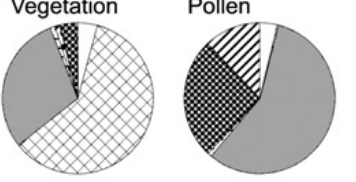

Fig. 8.

flowering of Alnus. By the end of March, this effect had largely been replaced by the increase in pasture types due to the beginning of flowering of Poaceae spp. (Fig. 9A). This rise in pasture types occurs in the upper subcatchments by July (Fig. 9B) when overall the pollen and spore representation is very similar to the relative proportions of land use classes with the exception of an under-representation of types characteristic of disturbed ground. This remains true in October 2000 and October 2001 (Fig. 10) although there are individual variations such as a very high flux of heath types from catchment 1 and high representation from the other headwater subcatchments (2 and 3). Overall these results show that the major control on the sub-catchment pollen and spore waterborne output is the spatial pattern of land use, however, that there are also very strong seasonal effects.

These peak values have been cumulated and can be compared with the airborne annual assemblage from Bickleigh (Fig. 11). As can be seen there is an underrepresentation in some herb types (e.g. Brassicaceae and 

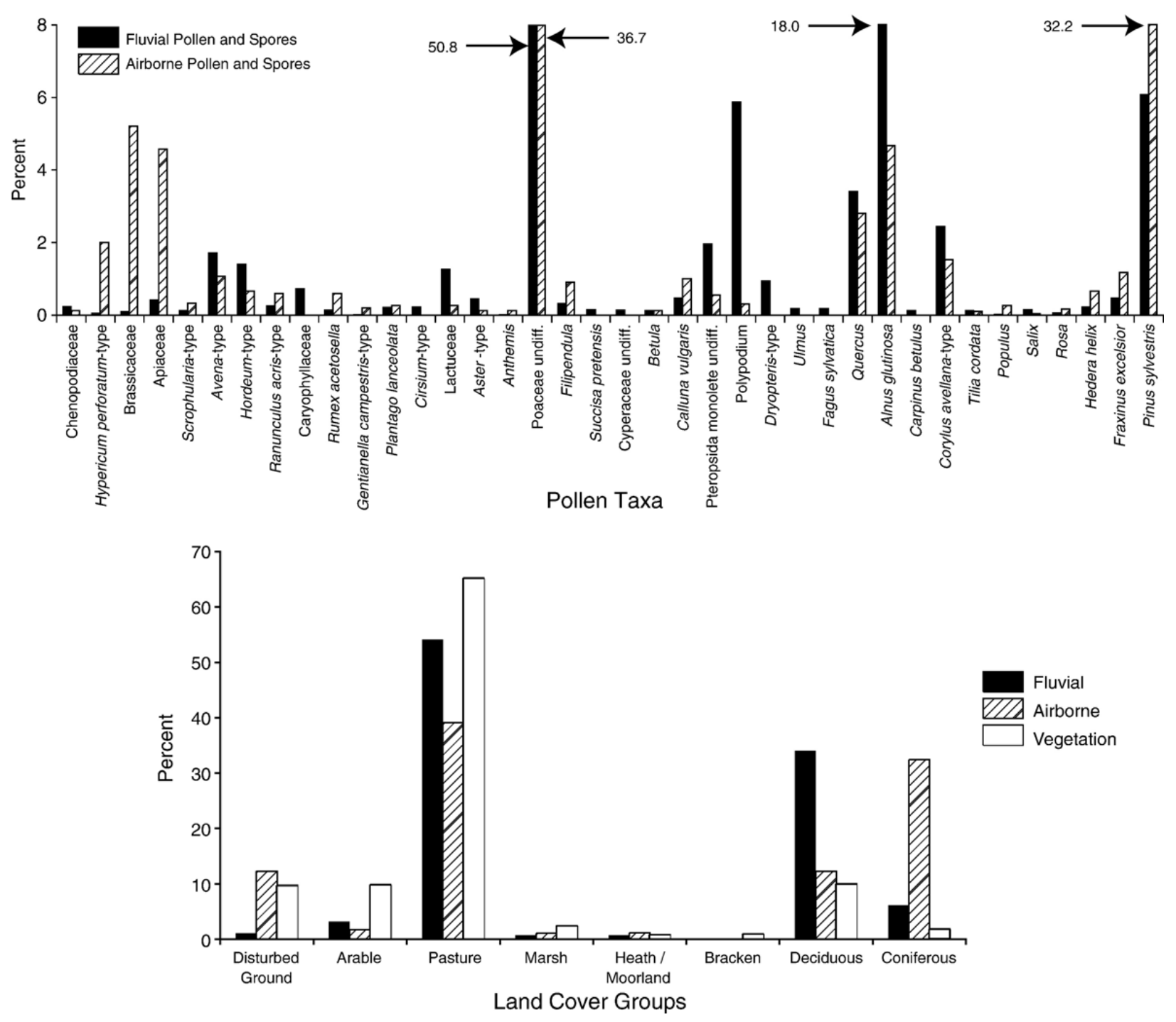

Fig. 9.

Apiaceae) and most notably Pinus, but an over-representation in arable types (e.g. Avena type), Poaceae, fern spores and most notably Alnus. Given the coincident location of the airborne traps and the stream sampling locations, it is suggested that this represents the different pollen and spore sources with greater importance of riparian vegetation, pasture adjacent to river courses and the contribution from the bed sediment store. However, it is also true that overall the waterborne pollen and spore values are a closer approximation of the catchment land use for arable, pasture, and coniferous classes but a poorer representation for disturbed ground, marsh, heath, and deciduous.

\section{Discussion and scenario modelling}

For lakes and marine sites where waterborne pollen is the major influx it follows that the assemblage must be constructed from a series of storm input spectra, which may or may not be blurred depending upon the water-bed sediment conditions. In order to try and predict the possible effects of land use changes on a fluvially derived assemblage, a modelling experiment was conducted. The monitoring produced data from between 15 and 20 flood events depending upon the sub-catchment. These data were used to cumulate steady state diagrams representing a cycle of 17 months for each of the sub-catchments. This was done by simply repeating the monitored flood series from the sub-catchment of interest and ignoring the low flow contribution. A change in land use was simulated by the substitution of one sub-catchment for another as indicated by the change in zones. Since the same underlying hydrological structure exists within the subcatchment data, this experiment only simulates a change in land use. Two scenarios were simulated (Fig. 10) and what is immediately noticeable is the high level to level 

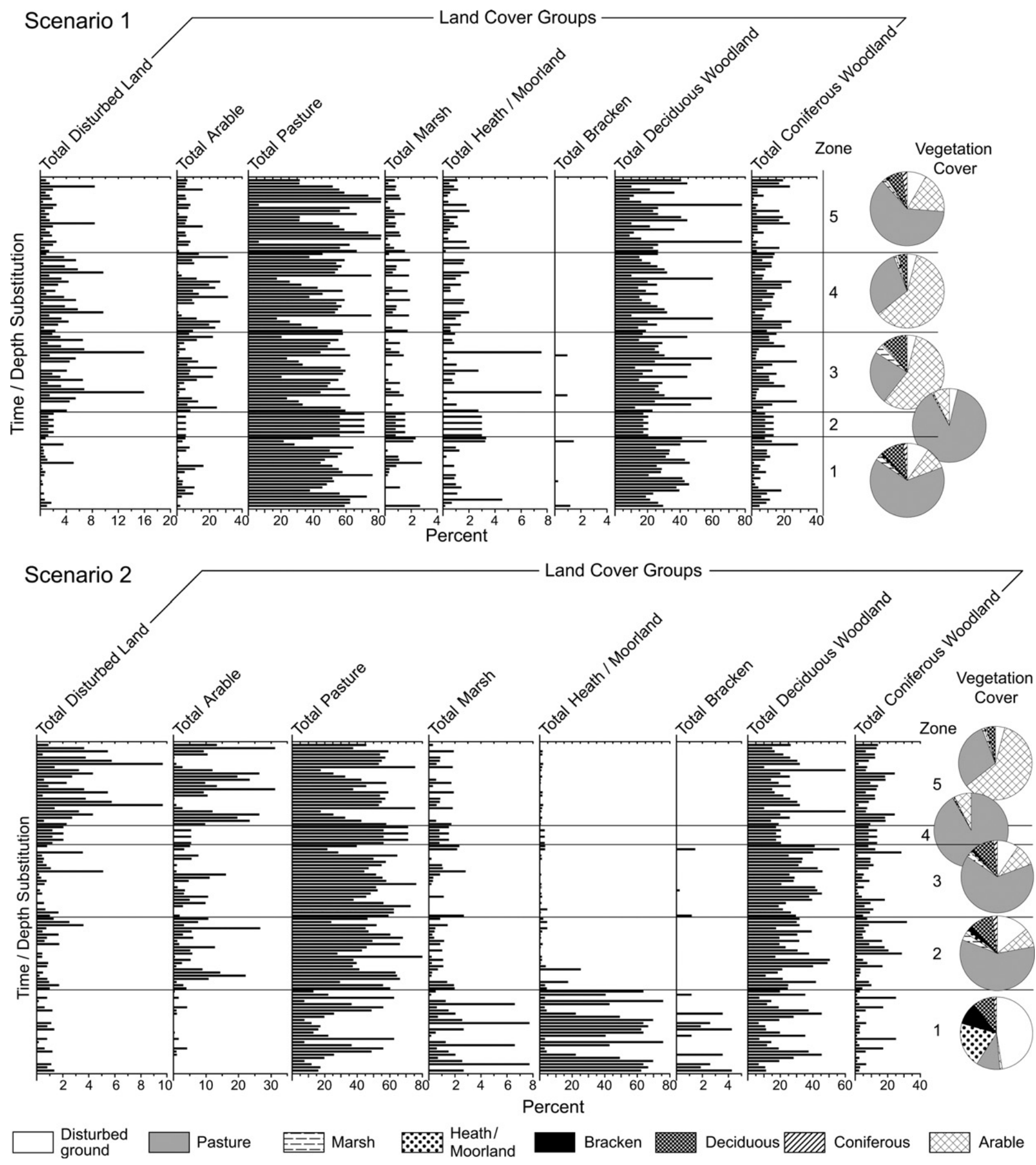

Fig. 10.

variation in all values. This is due to there being no mixing included in the model. This is directly comparable to some high-resolution pollen and spore diagrams from varved or laminated lake sediments which typically show these high-frequency fluctuations in values (e.g. Coard et al., 1983; Kerig and Lechterbeck, 2004). However, despite this high inter-level variation, the overall response of the assemblage is dampened in comparison with the dramatic changes in land cover. This accords with the general dampened response of many lake diagrams to human impact (Brown et al., 2005), particularly if land use classes have been used. What is also evident is particular artefacts, such as the single high peaks in heath, deciduous, marsh and arable types. These are all caused 
by seasonally related high influxes of particular pollen types such as Calluna/Erica, Alnus and Avena type.

Many floodplain or alluvial wetland pollen and spore diagrams also show anomalous peaks especially in close proximity to changes in lithology which is cause by hydrological change. Examples are peaks associated with discrete flood layers (e.g. Brown, 1988). Another example can be seen from Slapton Ley in Devon, England, where an alluvial pollen diagram shows a pronounced peak in Alnus prior to a dramatic influx of overbank sedimentation which coincided with an increase in damaged grains and arable indicators (Foster et al., 2000). In this case, the authors could link this alluviation directly to the combined affect of intense arable cultivation and climatic change and do not implicate any increase in the extent of alder woodland. Whilst stratigraphic changes in through-flow lake and alluvial sequences may mark changes in vegetation due to climate change or human impact they also are likely to represent a change in the pollen and spore source area and the ratio of airborne to waterborne pollen. In this respect, the strong relationship of waterborne pollen to catchment vegetation is beneficial as it can accentuate the effects of local environmental change. The frequency of corroded grains within lake sediments has also been associated with catchment disturbance and soil erosion (Wilshurt and McGlone, 2005a,b) and the results of this study support this association.

The results of this catchment monitoring also have implications for the interpretation of near-shore marine cores which still present difficulties of interpretation (Clark, 1986; Wilmshurst et al., 1999; McGlone, 2001). Studies on modern pollen deposition in coastal waters indicate the rapid incorporation of pollen to marine sediments (Chmura and Eisma, 1995). This is probably due to deposition through aggregation or incorporation into faecal pellets of zooplankton, as single-grain settling from suspension would take more than a year and lead to distant transport by marine currents (Mudie and McCarthy, 1994). As a result, pollen and spore concentrations increase with proximity to large fluvial inputs and within confined seas with high fluvial input discharges. An example is the eastern Mediterranean and Black Sea where there is a strong link between surface pollen concentrations and salinity with a minima of 5 grains $\mathrm{g}^{-1}$ in the Eastern Mediterranean and a maxima of 160,000 grains $\mathrm{g}^{-1}$ in the Black Sea (Sanchez Goni et al., 2002; Mudie et al., 2002). The high pollen and spore concentrations in deep-sea sediment cores but with high fluvial inputs, such as off the western Iberian coast, can provide waterborne pollen diagrams which can be used to infer vegetation change over large areas which track millennial-scale climate change (Baas et al., 1997; Roucoux et al., 2001).

\section{Conclusions}

This large-scale monitoring of fluvial pollen and spore waterborne transport has confirmed a number of previous conclusions derived from the limited monitoring of single sites. Firstly, that the pollen and spore water depth profile is generally uniform indicating full mixing, except for a surface enhancement effect. Secondly that the vast majority of fluvial input in temperate basins occurs during flood events and thirdly that the overall variation of fluvial input is controlled by catchment variation. However, this study has gone on to show that there are very strong seasonal effects causing both over and under-representation of catchment vegetation in the fluvial output. These reflect the pathways of pollen transport into rivers particularly direct input probably via leaf-drip of riparian vegetation, overland flow in autumn and winter, and bed sediment re-suspension. A particularly important finding is the high storage in river pool sediments of arable pollen grains and particularly damaged arable pollen grains. The exact cause of this is unknown but it may be due to the greater settling velocity of these large grains on the declining limb of winter-spring hydrographs in areas of high arable cultivation. Scenario modelling of eventcumulated curves for land-use change has shown several characteristics that can be seen in lake pollen and spore diagrams. These include the greater inter-level variability of varved sediment diagrams than non-varved diagrams, the overall dampened response of pollen and spore classes, and the occurrence of anomalous peaks in types caused by season dependant flushes from vegetation with good connectivity to river courses. However, this data also shows that it is the closer similarity of the waterborne pollen than the airborne pollen to catchment vegetation that is the cause of strong correspondence between small lakes with significant stream inputs with their catchment vegetation cover. Future work could develop these relationships in a quantitative fashion following a similar modelling approach to that for the airborne component (Prentice, 1985, 1986, 1988; Prentice and Parsons, 1983; Sugita et al., 1999; Fyfe, 2006; Caseldine and Fyfe, 2006) with the hope of improving the accuracy of pollen based vegetation reconstructions from lakes and marine sediments with substantial fluvial inputs.

\section{Acknowledgements}

The authors must thank many members of the Geography Department at Exeter for help with the 
monitoring and sample processing particularly J. Grapes and A. Ames. Additional cartographic help was provided by S. Rouillard. This work was conducted as part of NERC studentship and forms part of the Pollen Monitoring Programme.

\section{References}

Andrew, R. 1984. A Practical Pollen Guide to the British Flora. QRA Technical Guide, No. 1, QRA.

Baas, J.H., Mienert, J., Abrantes, F., Prins, M.A., 1997. Late Quaternary sedimentation on the Portuguese continental margin: climate-related processes and products. Palaeogeography, Palaeoclimatology, Palaeoecology 130, 1-23.

Bennett, K.D., Whittington, G., Edwards, K.J., 1994. Plant nomenclatural changes and pollen morphology in the British Isles. Quaternary Newsletter 73, 1-6.

Blake, W.H., Walling, D.E., He, Q., 2002. Using cosmogenic beryllium7 as a tracer in sediment budget investigations. Geografiska Annaler 84A, 89-102.

Bonny, A.P., 1978. The effect of pollen recruitment processes on pollen distribution over the sediment surface of a small lake in Cumbria. Journal of Ecology 66, 385-416.

Bonny, A.P., 1980. Seasonal and annual variation over 5 years in contemporary airborne pollen trapped at a Cumbrian lake. Journal of Ecology 68, 421-441.

Brown, A.G., 1985. The potential use of pollen in the identification of suspended sediment sources. Earth Surface Processes and Landforms $10,27-32$.

Brown, A.G., 1988. The palaeoecology of Alnus (alder) and the postglacial history of floodplain vegetation: pollen percentage and influx data from the West Midlands, U.K. New Phytologist 110, 425-436.

Brown, A.G., Hatton, J., O’Brien, C.E., Selby, K.A., Langdon, P.G., Stuijts, I., Caseldine, C.J., 2005. Vegetation, landscape and human activity in Midland Ireland: mire and lake records from the Lough Kinale-Derragh Lough area, Central Ireland. Vegetation History and Archaeobotany 14, 81-98.

Brown, A.G., Carpenter, R., Walling, D.E., in press. Monitoring the Fluvial Palynomorph Load and its Relationship to Suspended Sediment and Discharge. Hydrobiologia.

Brush, G.S., Brush, L.M., 1972. Transport of pollen in a sediment laden channel: a laboratory study. American Journal of Science 272, 359-381.

Caseldine, C.J., Fyfe, R.M., 2006. A modelling approach to locating and characterising elm decline/landnam clearances. Quaternary Science Reviews 25, 632-644.

Chmura, G.L., Eisma, D., 1995. A palynological study of surface and suspended sediments on a tidal flat - implications for pollen transport and deposition in coastal waters. Marine Geology 128, 183-200.

Clark, R.L., 1986. Pollen as a chronometer and sediment tracer, Burrinjuck Reservoir, Australia. Hydrobiologia 143, 63-69.

Coard, M.A., Cousin, S.M., Cuttler, A., Dean, H.J., Dearing, J.A., Eglington, T.I., Greaves, A.M., Lacey, K.P.B., O'Sullivan, P.E., Pickering, D.A., Rhead, M.M., Rodwell, J.K., Simola, H., 1983. Palaeolimnological studies of annually laminated sediments in Loe Pool, Cornwall, UK. In: Merilainen, J., Huttunen, P., Battarbee, R.W. (Eds.), Palaeolimnology, (Developments In Hydrobiology). Dr W. Junk, The Hague, pp. 185-191.
Collins, A.L., Walling, D.E., 2002. Selecting fingerprint properties for discriminating potential suspended sediment sources in river basins. Journal of Hydrology 261, 218-244.

Collins, A.L., Walling, D.E., Leeks, G.J.L., 1997a. Source type ascription for fluvial suspended sediment based on a quantitative composite fingerprinting technique. Catena 29 (1), 1-27.

Collins, A.L., Walling, D.E., Leeks, G.J.L., 1997b. Fingerprinting the origin of fluvial suspended sediment in larger river basins: combining assessment of spatial provenance and source type. Geografiska Annaler Series A, Physical Geography 79A (4), 239-254.

Crowder, A.A., Cuddy, D.G., 1973. Pollen in a small river basin: Wilton Creek, Ontario. In: Birks, H.J.B., West, R.G. (Eds.), Quaternary Plant Ecology. Blackwell Scientific Publisher, Oxford, pp. 961-977.

David, C., Roberts, N., 1990. Vegetation change and pollen recruitment in a lowland lake catchment - Groby-Pool, Leics (England). Hydrobiologia 214, 305-310.

Delcourt, P.A., Delcourt, H.R., 1980. Pollen preservation and Quaternary environmental history in the south-eastern United States. Palynology 4, 215-231.

Faegri, K., Iversen, J., 1989. Textbook of Pollen Analysis. John Wiley and Sons, Chichester.

Federova, K.V., 1952. Distribution of pollen and spores by flowing water. Works of the Geographical Institute of the Academy of Sciences, USSR, vol. 52, pp. 46-72 (in Russian).

Foster, I.D.L., Mighall, T.M., Wotton, C., Owens, P.N., Walling, D.E., 2000. Evidence for mediaeval soil erosion in the South Hams region of Devon, UK. Holocene 10 (2), 261-271.

Fuller, R.M., Groom, G.B., Jones, A.R., 1994. The Land Cover Map of Great Britain: an automated classification of landsat thematic mapper data. Photogrammetric Engineering and Remote Sensing 60, 553-562.

Fyfe, R.M., 2006. GIS and the application of a model of pollen deposition and dispersal: a new approach to testing landscape hypotheses using the POLLANDCAL models. Journal of Archaeological Science 33, 483-493.

Hicks, S., Hyvärinen, V.P., 1986. Sampling modern pollen deposition by means of 'Tauber traps': some considerations. Pollen et Spores 28, 219-242.

Holmes, P., 1990. Differential transport of spores and pollen - a laboratory study. Review of Palaeobotany and Palynology 64 (1-4), 289-296.

Holmes, P., 1994. The sorting of spores and pollen by water: experimental and field evidence. In: Traverse, A. (Ed.), Sedimentation of Organic Particles. Cambridge University Press, Cambridge, pp. 9-32.

Hopkins, J.S., 1950. Differential pollen flotation and deposition of conifers and deciduous trees. Ecology 31, 633-641.

Jacobson, G.L., Bradshaw, R.H.W., 1981. The selection of sites for palaeovegetational studies. Quaternary Research 16 (1), 80-96.

Kerig, T., Lechterbeck, J., 2004. Laminated sediments, human impact, and a multivariate approach: a case study in linking palynology and archaeology (Steisslingen, Southwest Germany). Quaternary International 113, 19-39.

Lambert, C.P., Walling, D.E., 1988. Measurement of channel storage of suspended sediment in a gravel-bed river. Catena 15 (1), 65-80.

McAndrews, J.H., Power, D.M., 1973. Palynology of the Great Lakes: the surface sediments of Lake Ontario. Canadian Journal of Earth Sciences 10, 777-792.

McGlone, M., 2001. A late Quaternary pollen record from marine core P69, southeastern North Island, New Zealand. New Zealand Journal of Geology and Geophysics 44, 69-77.

Meade, R.H., Yuzyk, T.R., Day, T.J., 1990. Movement and storage of sediment in rivers of the United States and Canada. In: Wolman, M.G., Riggs, H.C. (Eds.), The Geology of North America. 
Surface Water Hydrology, vol. 1. Geological Society of America, Boulder, Colorado, pp. 255-280.

Moore, P.D., Webb, J.A., Collinson, M.E., 1991. Pollen Analysis, Second Edition. Blackwell Science Publications, Oxford.

Mudie, P.J., McCarthy, F.M.G., 1994. Marine Geology 118, 79.

Mudie, P.J., Rochon, A., Aksu, A.E., 2002. Pollen stratigraphy of Late Quaternary cores from Marmara Sea: land-sea correlation and paleoclimatic history. Marine Geology 190, 233-260.

Nicholas, A.P., Walling, D.E., 1995. Modelling contemporary overbank sedimentation on floodplains: some preliminary results. River Geomorphology. John Wiley and Sons, Chichester, pp. 131-153.

Peck, R.M., 1973. Pollen budget studies in a small Yorkshire catchment. In: Birks, H.J.B., West, R.G. (Eds.), Quaternary Plant Ecology. Blackwell Scientific Publications, Oxford, pp. 43-60.

Peck, R. 1974. Studies of pollen distribution in the Oakdale Catchment. (PhD Thesis). Cambridge, Cambridge University, UK.

Pennington, W., 1979. The origin of pollen in lake sediments: an enclosed lake compared with one receiving inflow streams. New Phytologist 83, 189-213.

Prentice, I.C., 1985. Pollen representation, source area, and basin size toward a unified theory of pollen analysis. Quaternary Research 23 (1), 76-86.

Prentice, I.C., 1986. Forest-composition calibration of pollen data. In: Berglund, B.E. (Ed.), Handbook of Holocene Palaeoecology and Palaeohydrology. John Wiley and Sons, Chichester, pp. 799-816.

Prentice, I.C., 1988. Records of vegetation in time and space: the principles of pollen analysis. In: Huntley, B., Webb, T.I. (Eds.), Vegetation History. Kluwer Academic Publishers, Dordrecht, pp. 17-42.

Prentice, I.C., Parsons, R.W., 1983. Maximum likelihood linear calibration of pollen spectra in terms of forest composition. Biomectrics 39, 1051-1057.

Roucoux, K.H., Shackleton, N.J., de Abreu, L., Schonfeld, J., Tzedakis, P.C., 2001. Combined marine proxy and pollen analysis reveal rapid Iberian vegetational responses to North Atlantic millennial-scale climate oscillations. Quaternary Research 56, 128-132.

Sanchez Goni, M.F., Cacho, I., Turon, J.-L., Guiot, J., Sierro, F.J., Peypouquet, J.-P., Grimalt, J.O., Shackleton, N.J., 2002. Synchroneity between marine and terrestrial responses to millennial scale climatic variability during the last glacial period in the Mediterranean region. Climate Dynamics 19, 95-105.

Smirnov, A., Chmura, G.L., Lapointe, M.F., 1996. Spatial distribution of suspended pollen in the Mississippi River as an example of pollen transport in alluvial channels. Review of Palaeobotany and Palynology 92, 69-81.

Starling, R.N., Crowder, A., 1981. Pollen in the Salmon River System, Ontario, Canada. Review of Palaeobotany and Palynology 31 (3-4), 311-334.

Stockmarr, J., 1971. Tablets with spores used in absolute pollen analysis. Pollen et Spores 13, 615-621.
Sugita, S., Gaillard, M.-J., Broström, A., 1999. Landscape openness and pollen records: a simulation approach. The Holocene 9, 409-421.

Tauber, H., 1974. A static non-overload pollen collector. New Phytologist 73, 359-369.

Traverse, A., 1988. Paleopalynology. Unwin Hyman, London.

Traverse, A., Ginsburg, R.N., 1966. Palynology of the surface sediments of the Great Bahama Bank, as related to water movement and sedimentation. Marine Geology 4, 417-459.

Traverse, A., 1992. Organic fluvial sediment - palynomorphs and palynodebris in the lower Trinity River, Texas. Annals of the Missouri Botanical Garden 79 (1), 110-125.

Traverse, A., 1994. Sedimentation of land-derived palynomorphs in the Trinity-Galveston Bay Area, Texas. In: Traverse, A. (Ed.), Sedimentation of Organic Particles. Cambridge University Press, Cambridge, pp. 69-102.

Walling, D.E., He, Q., 1994. Rates of overbank sedimentation on the floodplains of several British rivers during the past 100 years. In: O., L.J., Loughran, R.J., Kesby, J.A. (Eds.), Variability in Stream Erosion and Sediment Transport, 224. IAHS Publication, Wallingford, pp. 203-210.

Walling, D.E., Moorehead, P.W., 1987. Spatial and temporal variation of the particle-size characteristics of fluvial suspended sediment. Geografiska Annaler Series A, Physical Geography 69, 47-59.

Walling, D.E., Webb, B.W., 1981. The reliability of suspended sediment load data. Erosion and Sediment Transport Measurement. Proceedings of the Florence Symposium, June 1981, vol. 133. IAHS Publication, Wallingford, pp. 177-194.

Walling, D.E., Woodward, J.C., 1993. Use of a field based water elutriation system for monitoring the in situ particle size characteristics of fluvial suspended sediment. Water Research 27, 1413-1421.

Walling, D.E., Woodward, J.C., Nicholas, A.P., 1993. A multi-parameter approach to fingerprinting suspended-sediment sources. Tracers in Hydrology, vol. 215. IAHS Publication, Wallingford, pp. 329-338.

Webb, B.W., 1980. Solute levels in streams of the Middle and Upper Exe basin. (Unpublished Ph.D. Thesis). Exeter, University of Exeter, U.K.

Wilmshurst, J.M., Eden, D.N., Froggatt, P.C., 1999. Late Holocene forest disturbance in Gisborne, New Zealand: a comparison of terrestrial and marine pollen records. New Zealand Journal of Botany 37, 523-554.

Wilshurt, J.M., McGlone, M.S., 2005a. Origin of pollen and spores in surface lake sediments: comparison of modern palynomorph assemblages in moss cushions, surface soils and surface lake sediments. Review of Palaeobotany and Plynology 136, 1-15.

Wilshurt, J.M., McGlone, M.S., 2005b. Corroded pollen and spores as indicators of changing lake sediment sources and catchment disturbance. Journal of Paleolimnology 34, 503-517. 